\title{
PENERAPAN MODEL PEMBELAJARAN KOOPERATIF TIPE STAD PADA MATERI GUGUS FUNGSI UNTUK MENINGKATKAN HASIL BELAJAR SISWA KELAS XII IPA SMA NEGERI 1 ELAR
}

\author{
LEONARDUS JAFAR \\ SMA Negeri 1 Elar, Nusa Tenggara Timur \\ e-mail: Jafarleonardus@gmai.com
}

\begin{abstract}
ABSTRAK
Model pembelajaran kooperatif aktifitas pembelajaran lebih menekankan pada kesadaran siswa untuk belajar berpikir, memecahkan masalah, mengaplikasikan pengetahuan, konsep dan ketrampilan kepada anggota kelompok lain yang membutuhkan dan merasa senang menyumbangkan pengetahuan dalam kerja kelompok. Pembelajaran kooperatif tipe STAD yang dilaksanakan guru telah mampu menumbuhkan dan meningkatkan motivasi belajar siswa sehingga prestasi belajar siswa kelas XII IPA SMAN 1 Elar meningkat. Terutama adanya penghargaan yang diberikan guru pada kelompok terbaik. Pemberian penghargaan ini telah memunculkan efek positif pada siswa. siswa semakin antusias untuk belajar.Hal ini dibuktikan dengan hasil ulangan harian meningkat dari siklus 1 ke siklus 2, baik dari persentase ketuntasan klasikal maupun rata-rata kelas. Kenaikan tersebut sebanyak 19,32\% untuk ketuntasan klasikal dan 6,81 untuk rata-rata kelas. Adanya peningkatan tersebut disebabkan pengelolaan pembelajaran kooperatif tipe STAD telah berlangsung secara efektif. Pada siklus 2 guru telah mampu mengatasi segala hal yang menghambat kegiatan belajar mengajar dengan mengadakan perbaikan-perbaikan pada beberapa aspek yang dirasa masih kurang. Secara keseluruhan kegiatan pembelajaran kooperatif tipe STAD berlangsung baik sehingga dapat dikatakan bahwa pengelolaan kegiatan pembelajaran berlangsung secara efektif.
\end{abstract}

Kata Kunci: Kooperatif tipe STAD, Gugus Fungsi, Hasil belajar

\section{PENDAHULUAN}

Rendahnya mutu dan kwalitas pendidikan Indonesia merupakan salah satu dari beberapa masalah pendidikan nasional saat ini. Sekolah seyogyanya sebagai salah satu penentu peningkatan mutu pendidikan nasional banyak menghadapi permasalahan baik secara umum maupun secara khusus. Guru merupakan salah satu komponen di dunia pendidikan yang memiliki peran yang sangat penting dalam membantu membimbing dan mendidik karakter anak didiknya. Hal tersebut sesuai dengan Undang-Undang Republik Indonesia nomor 14 tahun 2005. Tugas seorang guru tidak hanya menyampaikan informasi kepada peserta didik, tetapi harus kreatif memberikan layanan dan kemudahan belajar (facilitate learning) kepada seluruh peserta didik agar mereka dapat belajar dalam suasana yang menyenangkan, gembira, penuh semangat dan tidak membosankan. Guru harus bisa memilih pendekatan dan metode yang variatif dan sesuai dengan materi yang akan diajarkan kepada peserta didik, agar tujuan pembelajaran yang telah ditentukan dapat tercapai. Guru dituntut berperan secara aktif sebagai motivator dan fasilitator dalam pembelajaran agar siswa dapat memahami konsep-konsep yang dipelajari melalui pengalaman lansung. Hal tersebut bertujuan agar siswa mendapatkan penalaman bermakna dari apa yang telah mereka lakukan. Selain itu guru diharapkan mampu membuat rancangan pembelajaran yang unik dan semenarik mungkin, agar peserta didik tidak cepat bosan saat berada di dalam kelas dan peserta didik mampu fokus dalam menerima materi pada saat proses pembelajaran berlangsung. Guru adalah pendidik profesional dengan tugas utama mendidik, mengajar, membimbing, mengarahkan, melatih, menilai dan mengevaluasi peserta didik pada pendidikan anak usia dini jalur pendidikan formal, pendidikan dasar, dan pendidikan menengah". Selain itu guru diharapkan mampu membuat rancangan pembelajaran yang unik dan semenarik mungkin, agar peserta didik tidak cepat bosan saat berada di dalam kelas dan peserta didik mampu fokus dalam menerima materi pada saat pembelajaran berlangsung. Pembelajaran Kooperatif Learning tipe STAD memberi kesempatan belajar yang lebih luas dan suasana kondusif kepada siswa untuk mengembangkan sikap, nilai, dan 
keterampilan sosial yang bermanfaat bagi kehidupan bermasyarakat. Guru bukan lagi berperan sebagai satu-satunya narasumber pembelajaran melainkan berperan sebagai mediator, fasilitator, dinamisator, dan manajer pembelajaran. Siswa yang memiliki motivasi berprestasi tinggi selalu terdorong untuk terlibat secara aktif dalam proses pembelajaran. Siswa yang memiliki motivasi berprestasi tinggi juga tekun dalam menghadapi tugas, ulet, dan tidak mudah menyerah dalam menghadapi kesulitan, memiliki minat yang tinggi terhadap bermacammacam masalah, bekerja mandiri, dapat mempertahankan pendapat dan senang mencari serta memecahkan masalah. Model diartikan sebagai jalan atau cara yang harus dilalui untuk mencapai tujuan tertentu. Pemilihan model pembelajaran turut menentukan berhasil tidaknya proses pembelajaran. Model pembelajaran merupakan pola yang digunakan untuk mengorganisasikan pengalaman belajar untuk siswa dalam rangka mencapai tujuan pembelajaran. Model pembelajaran merupakan kerangka konseptual yang menggambarkan prosedur dalam mengorganisasikan pengalaman pembelajaran untuk mencapai tujuan pembeljaran. Model pembelajaran berfungsi sebagai pedoman bagi guru dalam merencanakan dan melaksanakan kegiatan pembelajaran. Model pembelajaran adalah suatu rencana atau pola yang dapat digunakan untuk membentuk kurikulum (rencana pembelajaran jangka panjang), merancang bahan-bahan pelajaran, dan membimbing pembelajaran di kelas atau yang lain". Salah satu masalah khususnya pembelajaran kimia di kelas adalah rendahnya prestasi belajar siswa. Hal ini nampak sekali pada hasil ulangan harian kimia.Dari hasil analisa ulangan harian siswa materi tentang penulisan struktur dan nama senyawa karbon berdasarkan gugus fungsi ditemukan pencapaian kemampuan siswa sangat rendah dari standar KKM yang harus dicapai siswa. Hal ini disebabkan siswa kurang memahami materi cara menuliskan struktur dan nama senyawa karbon berdasarkan gugus fungsi. Untuk mengatasi masalah tersebut, guru harus menciptakan proses kegiatan belajar mengajar yang mampu mengembangkan hasil belajar yang optimal.

Untuk mendisain kegiatan belajar mengajar yang dapat merangsang hasil belajar secara efektif dan efisien untuk setiap materi pelajaran diperlukan kemampuan mengajar guru senantiasa ditingkatkan, antara lain penguasaan berbagai metode pangajaran dan diaplikasikan dengan model - model pembelajaran yang tepat dimana Siswa dirangsang untuk mengkonstruksi pengetahuan yang dimilikinya. Beberapa model pembelajaran dapt diadopsi dalam satu pokok bahasan dari setiap pelajaran di sekolah. Kimia merupakan ilmu yang termasuk dalam rumpun IPA. Dalam pembelajaran kimia lebih menekankan pada pemberian dan pengalaman belajar langsung melalui penggunaan dan pengembangan ketrampilan proses dan sikap ilmiah. Ada 2 hal yang berkaitan dengan kimia yang tidak terpisahkan yaitu kimia sebagai produk ( pengetahuan kimia yang berupa fakta, konsep, prinsip, hukum dan teori temuan ilmuwan) dan kimia sebagai proses ( kerja ilmiah). Dengan menerapkan model pembelajaran kooperatif pada kegiatan belajar mengajar, diharapkan hasil belajar siswa dapat ditingkatkan dan prestasi belajar kimia dapat dioptimalkan. Pada model pembelajaran kooperatif tipe STAD aktifitas pembelajaran lebih menekankan pada kesadaran siswa untuk belajar berpikir, memecahkan masalah, mengaplikasikan pengetahuan, konsep dan ketrampilan kepada anggota kelompok lain yang membutuhkan dan merasa senang menyumbangkan pengetahuan dalam kerja kelompok. Dasar pembelajaran kooperatif yaitu peserta didik memiliki persepsi tanggung jawab dan tujuan yang sama dalam kelompoknya. Dalam pembelajaran kooperatif ini, peranan guru difokuskan pada pendesaian peta konsep, persiapan bahan ajar, memfasilitas kerja kelompok dan diskusi antara kelompok dengan kelompok serta mengobservasi dan mengevaluasi kegiatan siswa. 
Tabel 1. Hasil Angket Siswa sebagai Refleksi Awal

\begin{tabular}{|llll|}
\hline No & Aspek & Penilaian & \\
\hline 1. & Kimia merupakan pelajaran yang sulit & Ya & Tidak \\
\hline 2. & $\begin{array}{l}\text { Guru pernah menggunakan model pembelajaran kooperatif } \\
\text { 3. }\end{array}$ & $0 \%$ & $45,45 \%$ \\
& $\begin{array}{l}\text { Anda merasa senang dengan metode yang diterapkan oleh guru } \\
\text { anda selama ini }\end{array}$ & $58,06 \%$ & $41,94 \%$ \\
4. & $\begin{array}{l}\text { Anda merasa termotivasi untuk belajar saat guru anda } \\
\text { mengajar }\end{array}$ & $51,61 \%$ & $48,39 \%$ \\
5. Anda menginginkan adanya model pembelajaran yang baru & $100 \%$ & $0 \%$ \\
6. & $\begin{array}{l}\text { Apakah anda puas dengan hasil ulangan harian yang anda } \\
\text { peroleh }\end{array}$ & $51,61 \%$ & $48,39 \%$ \\
\end{tabular}

Data diatas menunjukkan bahwa sebagian besar siswa kelas XI IPA SMAN 1 Elar menyatakan Kimia merupakan pelajaran yang sulit (54,55\%) dan 45,45\% siswa merasa tidak puas terhadap hasil ulangan yang diperoleh. Siswa merasa jenuh dengan metode mengajar yang selama ini diterapkan. Semua siswa (100\%) menginginkan adanya variasi model pembelajaran, dan siswa merasa kurang termotivasi untuk belajar dengan metode yang selama ini diterapkan. Berkaitan dengan uraian pemikiran dan angket refleksi awal diatas, maka penulis ingin melakukan penelitian dengan judul : Penerapan Model Pembelajaran Kooperatif Tipe STAD Pada Materi Gugus Fungsi Untuk Meningkatkan Hasil Belajar Siswa Kelas XII IPA SMA Negeri 1 Elar.

\section{METODE PENELITIAN}

Prosedur penelitian yang digunakan dalam penelitian ini adalah penelitian tindakan kelas. Rancangan yang digunakan adalah model rancangan yang dikembangkan oleh Stephen Kemmis dan Mc. Taggart (dalam Arikunto, 2006:97) dengan menggunakan dua siklus, masingmasing siklus terdiri dari empat tahap yakni: 1) Merencanakan (plan), 2) Melakukan Tindakan (act), 3) Mengamati (observe), 4) Refleksi (reflect).

Berikut ini adalah gambar rancangan penelitian tindakan kelas menurut Stephen Kemmis dan Mc. Taggart.

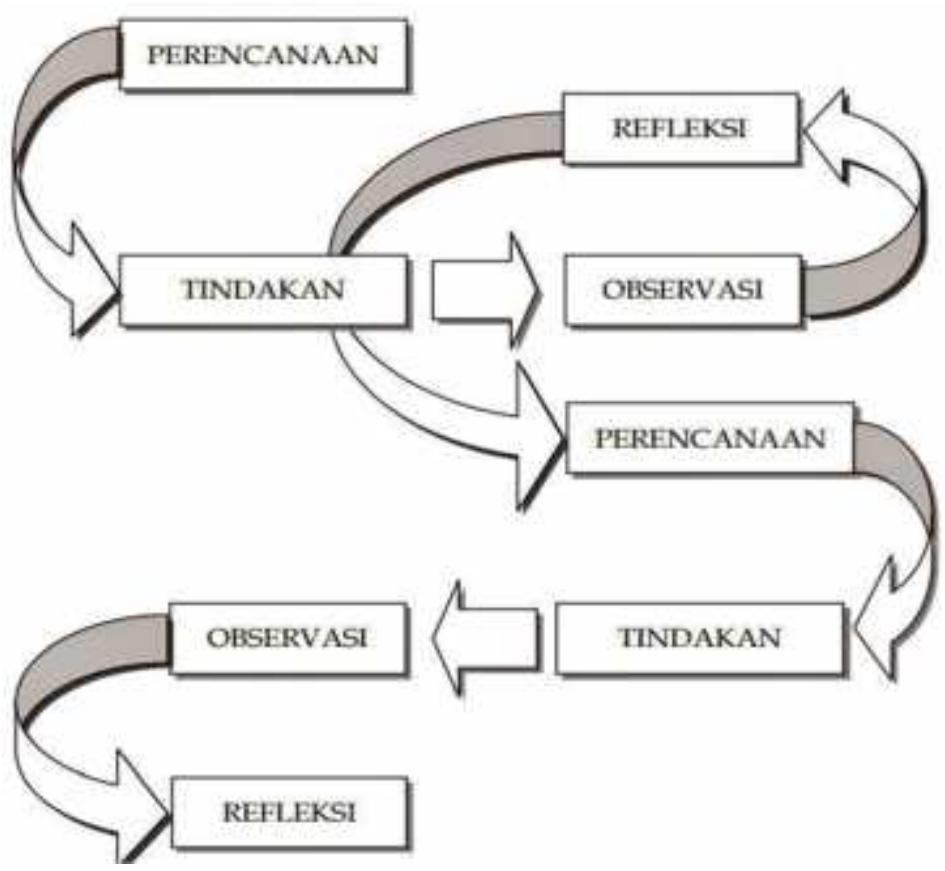

Tahapan dalam siklus Penelitian Tindakan Kelas Model Kemmis \& Taggart.

Sumber: Arikunto,2006:97. 
Penelitian ini dilakukan dengan tindakan yang dilaksanakan dengan langkah-langkah penelitian yang telah direncanakan, yaitu dengan terlebih dahulu menyusun RPP yang berisi langkah-langkah dalam pelaksanaan pembelajaran. Langkah selanjutnya adalah berupaka pengumpulan data yang dilalksanakan dengan melakukan observasi, pre test maupun post test. Setelah data diperoleh kemudian dilakukan refleksi dan melakukan laporan hasil penelitian. Data yang diperoleh dari penelitian ini berupa data awal yang didapatkan dari data pre tindakan, data yang diperoleh pada saat tindakan dan data hasil tindakan. P0eneliti memperoleh data awal tindakan dari hasil observasi di kelas sebelum ada tindakan. Dari data awal didapatkan informasi bahwa peserta didik memerlukan tindakan untuk memecahkan permasalahan rendahnya kemampuan pemahaman materi reading comprehension.

Data inti diperoleh selama tindakan. Dari hasil tindakan diperoleh data verbal yaitu data yang dipeoleh peneliti selama observasi. Dalam data ini peneliti mencatat aktiffitas peserta didik dan juga aktifitas yang dilakukan guru selama tindakan berlangsung. Data ini selanjutnya dikategorikan data aktifitas peserta didik dan data aktifitas guru. Selain data verbal, peneliti memproleh data non verbal yang didapatkan dari hasil post test sesudah tindakan siklus I dan siklus II. Dari tampilan data baik verbal maupun non verbal, peneliti memperoleh hasil refleksi yang didukung oleh guru dan teman sejawat yaitu berupa kelemahan-kelemahan serta hambatan yang ditemukan yang selanjutkan dipakai sebagai dasar perbaikan pada siklus berikutnya.

\section{HASIL DAN PEMBAHASAN}

Pelaksanaan tindakan pada siklus 1 terbagi menjadi 1 kali pertemuan.. yang berlangsung selama 2 X 45 menit. Pelaksanaan tindakan dimulai dengan kegiatan pendahuluan yang berupa guru membuka pelajaran dan mengecek pengetahuan awal siswa tentang Gugus Fungsi. Kegiatan pendahuluan ini berlangsung selama 10 menit. Pada kegiatan inti, guru membagi siswa dalam kelompok-kelompok belajar kemudian membagikan LKS pada masing-masing kelompok dan meminta siswa membaca LKS atau buku yang relevan. Pada saat pembentukan kelompok siswa agak ribut dan ramai. Guru melakukan presentasi kelas dilanjutkan dengan tanya jawab dan meminta masing-masing kelompok menyiapkan alat-alat yang diperlukan untuk mengerjakan dalam buku LKS. Ada beberapa siswa yang kurang aktif dalam kelompok. Guru membimbing masing-masing kelompok berdiskusi dalam menyelesaikan kegiatan 1 dan 2. Ada satu atau dua siswa pada masing-masing kelompok yang kurang peduli terhadap kegiatan yang dikerjakan oleh teman yang lain. Guru meminta beberapa kelompok mempresentasikan hasil kerja kelompok dan meminta kelompok lain menanggapinya. Guru meminta masing-masing kelompok mengumpulkan hasil kerjanya. Kemudian silanjutkan dengan post test. Kegiatan inti berlangsung selama 70 menit. Pada kegiatan penutup guru mengajak siswa melakukan refleksi dengan mengadakan tanya jawab secara lisan. Guru meminta siswa membuat kesimpulan. Guru memberi tugas untuk dikerjakan dirumah. Kegiatan penutup ini berlangsung selama 10 menit. Pengamatan dan penilaian terhadap siswa dilakukan oleh peneliti. Pada siklus 1 ini tidak semua siswa antusias mengikuti pelajaran. Hasil ulangan harian siswa juga belum menunjukkan hasil yang cukup memuaskan. Ketuntasan klasikal mencapai 54,83\% dengan rata-rata 64,61. Berdasarkan hasil observasi dan evaluasi selama pelaksanaan siklus 1 , ada beberapa hal penting yang perlu diperhatikan dan diperbaiki untuk rencana tindakan pada siklus berikutnya. Dalam kegiatan pembelajaran yang telah dilaksanakan, guru telah berusaha tampil dengan baik dan memenuhi seluruh aspek pembelajaran kooperatif tipe STAD. Dari hasil observasi ada beberapa hal yang perlu diperbaiki dalam pengelolaan pembelajaran antara lain: guru kurang memotivasi siswa dalam belajar dan kurang membimbing seluruh kelompok dalam kegiatan kelompok sehingga tidak semua siswa terlibat dalam kegiatan kelompok. Untuk mengatasi hal tersebut peneliti dan observer saling memberi masukan agar pada siklus berikutnya guru tampil dengan lebih baik. Guru harus berusaha memberi bimbingan yang merata pada semua kelompok sehingga tidak ada kelompok yang merasa tidak diperhatikan dan semua siswa terlibat secara aktif dalam pembelajaran. 
Dari hasil observasi terhadap proses pembelajaran ada hal yang perlu diperbaiki untuk rencana tindakan pada siklus berikutnya yaitu dalam kelompok kooperatif, tidak semua siswa aktif mengerjakan kegiatan dalam LKS, terutama pada pertemuan pertama. Ada satu atau dua siswa pada masing-masing kelompok yang kurang peduli terhadap kegiatan yang dikerjakan oleh teman yang lain. Untuk mengantisipasi agar hal ini tidak terulang pada siklus berikutnya maka bimbingan guru harus menyeluruh pada semua kelompok dan diharapkan terjadi pembagian tugas yang merata antar anggota kelompok.

Berdasarkan hasil refleksi siklus 1, maka rencana tindakan pada siklus 2 adalah sebagai berikut: Menyusun rencana pelajaran, menyiapkan instrumen penelitian berupa: kartu soal ulangan harian, kunci jawaban dan, menyiapkan media pembelajaran. Pelaksanaan tindakan pada siklus 2 terbagi menjadi 1 kali pertemuan. yang berlangsung selama 2 X 45 menit. Pelaksanaan tindakan dimulai dengan kegiatan pendahuluan yang berupa guru mengecek pengetahuan awal siswa tentang cara menentukan konsentrasi larutan. Guru menulis tujuan pembelajaran. Kegiatan pendahuluan berlangsung selama 10 menit. Pada kegiatan inti guru meminta siswa berada dalam kelompoknya masing-masing. Siswa tertib dan tidak begitu ramai. Guru meminta siswa melakukan percobaan dalam kelompok. Guru mengingatkan kembali pada siswa bahwa saat kerja kelompok, semua siswa dalam kelompok harus saling bekerja sama. Begitu juga saat kegiatan diskusi kelompok dan diskusi kelas agar semua siswa terlibat secara aktif, baik dalam mengajukan pertanyaan maupun jawaban. Guru membimbing siswa dalam mengerjakan kegiatan percobaan tersebut dan berusaha membimbing semua kelompok. Semua siswa dalam kelompok saling bekerja sama dalam menyelesaikan tugas. Guru meminta beberapa kelompok mempresentasikan hasil kerja kelompok dan kelompok lain menanggapinya. Dilanjutkan dengan test akhir secara individu. Kegiatan inti berlangsung selama 70 menit.Pada kegiatan penutup guru. bersama dengan siswa membuat kesimpulan, kemudian memberikan tugas berupa laporan praktikum. Kegiatan penutup ini berlangsung selama 10 menit. Selama kegiatan pembelajaran berlangsung, diadakan pengamatan dan penilaian terhadap siswa.. Dalam kegiatan pembelajaran, guru telah memenuhi seluruh aspek pembelajaran kooperatif. Hal ini terjadi karena guru telah mampu menumbuhkan motivasi siswa dalam belajar. Guru telah melakukan bimbingan yang menyeluruh pada semua kelompok. Hasil ulangan harian mencapai rata-rata 71,42 dengan ketuntasan klasikal 74,19\%. Berdasarkan hasil observasi dan tes kognitif selama siklus 2 berlangsung, diperoleh data bahwa guru telah berhasil menerapkan pembelajaran kooperatif tipe STAD.

Hasil ulangan harian meningkat dari siklus 1 ke siklus 2. Hal ini dapat dilihat pada Gambar 4.2 berikut.

Gambar 4.2 Diagram Batang Hasil Ulangan Harian pada Siklus 1 dan 2

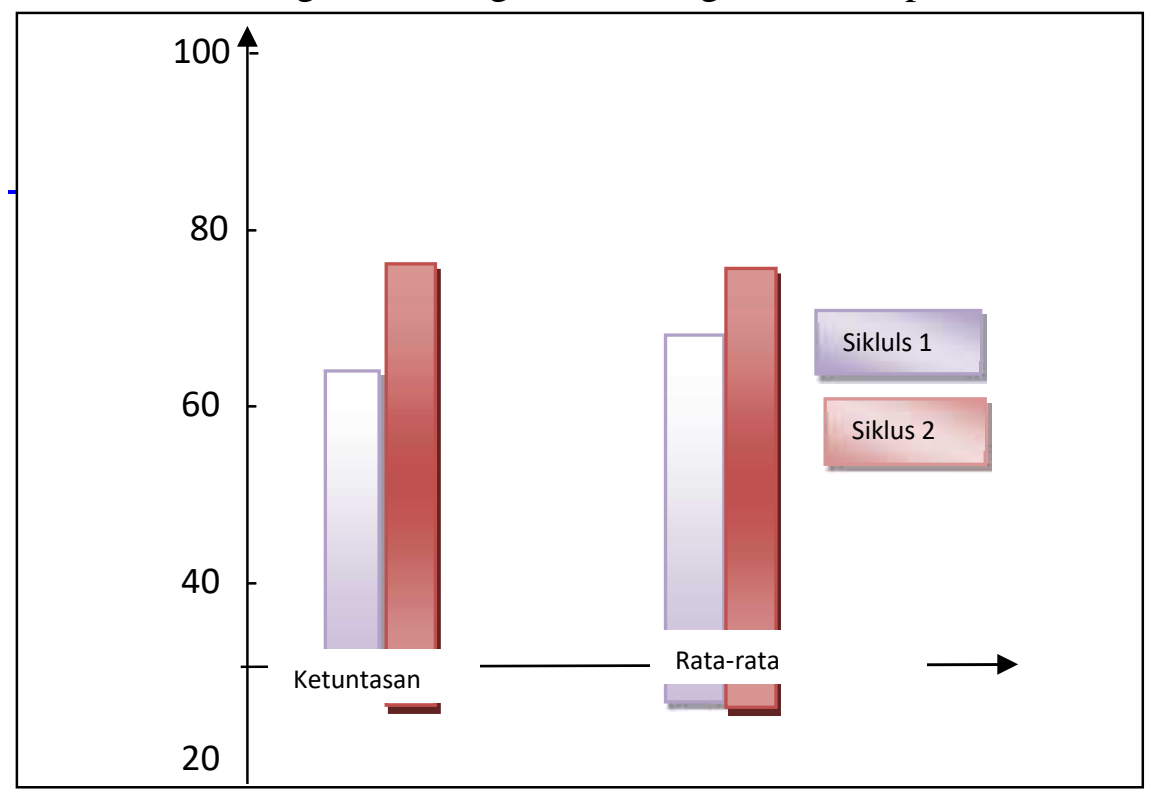


Pengelolaan Pembelajaran pada siklus 1 belum sepenuhnya berjalan dengan baik. Terlihat siswa belum terbiasa dengan pembelajaran kooperatif. Siswa belum memahami tugas mereka dalam pembelajaran kooperatif ini. Hal ini disebabkan kurangnya motivasi dan bimbingan guru sehingga sebagian besar siswa bersifat pasif. Hanya sebagian kecil saja siswa yang aktif dalam kegiatan pembelajaran, baik pada saat kerja kelompok maupun pada saat diskusi kelas. Alokasi waktu yang tersedia pada rencana pembelajaran tidak tercapai dengan tepat, dimana guru kurang melakukan transisi efisiensi pada saat membentuk kelompok sehingga waktu yang tersedia tidak cukup.

Pada siklus 2 guru telah mampu mengelola pembelajaran dengan cukup baik dan siswa nampak sudah bisa beradaptasi dengan pembelajaran kooperatif. Guru telah mampu membangkitkan motivasi belajar siswa dan bimbingan guru merata pada semua siswa. Hanya sebagian kecil saja siswa yang terlihat pasif dalam kegiatan pembelajaran baik pada saat kerja kelompok maupun pada saat diskusi kelas. Pengaturan waktu sudah sangat baik sehingga KBM berjalan sesuai skenario. Pada siklus 2 ini guru telah mampu mengatasi segala hal yang menghambat kegiatan belajar mengajar dengan mengadakan perbaikan-perbaikan pada beberapa aspek yang dirasa masih kurang. Secara keseluruhan kegiatan pembelajaran kooperatif berlangsung baik sehingga dapat dikatakan bahwa pengelolaan kegiatan pembelajaran berlangsung secara efektif.

Pada data hasil ulangan harian meningkat dari siklus 1 ke siklus 2, baik dari persentase ketuntasan klasikal maupun rata-rata kelas. Kenaikan tersebut sebanyak 19,32\% untuk ketuntasan klasikal dan 6,81 untuk rata-rata kelas. Adanya peningkatan tersebut disebabkan pengelolaan pembelajaran kooperatif telah berlangsung secara efektif. Hal ini sesuai dengan pendapat Ibrahim (2000), bahwa model ini unggul dalam membantu siswa memahami konsepkonsep sulit dan struktur penghargaan kooperatif telah dapat meningkatkan penilaian siswa pada belajar akademik dan perubahan norma yang berhubungan dengan hasil belajar. Didukung oleh pendapat Nur dkk. (2000) bahwa manfaat pembelajaran kooperatif bagi siswa dengan hasil belajar yang rendah, antara lain meningkatkan pencurahan waktu pada tugas, rasa harga diri menjadi lebih tinggi, memperbaiki kehadiran, angka putus sekolah menjadi rendah, penerimaan terhadap perbedaan individu menjadi lebih besar, perilaku mengganggu menjadi lebih kecil, konflik antarpribadi berkurang, sikap apatis berkurang, pemahaman yang lebih mendalam, motivasi lebih besar, hasil belajar lebih tinggi, retensi lebih lama dan meningkatkan kebaikan budi, kepekaan, dan toleransi.

Pembelajaran kooperatif tipe STAD yang dilaksanakan guru telah mampu menumbuhkan dan meningkatkan motivasi belajar siswa sehingga prestasi belajar siswa kelas XI IPA SMAN 1 Elar meningkat. Terutama adanya penghargaan yang diberikan guru pada kelompok terbaik. Pemberian penghargaan ini telah memunculkan efek positif pada siswa. siswa semakin antusias untuk belajar. Hal ini didukung oleh pendapat Nur (2001) bahwa salah satu cara memunculkan motivasi pada siswa adalah menonjolkan hal yang positif, dengan mengetahui kekuatankekuatan siswa dan menggunakan kekuatan itu sebagai bahan dasar untuk membangun.

\section{KESIMPULAN}

Kimia merupakan ilmu yang termasuk dalam rumpun IPA. Dalam pembelajaran kimia lebih menekankan pada pemberian dan pengalaman belajar langsung melalui penggunaan dan pengembangan ketrampilan proses dan sikap ilmiah. Ada 2 hal yang berkaitan dengan kimia yang tidak terpisahkan yaitu kimia sebagai produk (pengetahuan kimia yang berupa fakta, konsep, prinsip, hukum dan teori temuan ilmuwan) dan kimia sebagai proses (kerja ilmiah). Pembelajaran kooperatif tipe STAD yang dilaksanakan guru telah mampu menumbuhkan dan meningkatkan motivasi belajar siswa sehingga prestasi belajar siswa kelas XII IPA SMAN 1 Elar meningkat. Berdasarkan data hasil penelitian maka diperoleh peningkatan prestasi belajar yang diperoleh adalah sebanyak 19,32\% untuk ketuntasan klasikal dan 6,81 untuk rata-rata kelas. Penerapan model pembelajaran kooperatif tipe STAD dapat meningkatkan prestasi belajar siswa kelas X.I IPA SMAN 1 Elar. 


\section{DAFTAR PUSTAKA}

Adun Rusyana, 2003, Prinsip-prinsip Pembelajaran, Aris Family Publiser, Ciamis

Arikunto, S., Suhardjono, Supadi. 2012. Penelitian Tindakan Kelas. Jakarta: Bumi Aksara.

Andrian, dkk. 2020. Pengaruh Pembelajaran Kooperatif Tipe STAD Terhadap Peningkatan Hasil Belajar, Sikap Sosial, dan Motivasi Belajar. Jurnal Inovasi Matematika (Inomatika). 2(1), 65-75.

Bakhtiar, Yusrizal dan Khaldun 2016. Penggunaan Model Pembelajaran Kooperatif Tipe STAD Untuk Meningkatkan Motivasi dan Hasil Belajar Siswa Pada MateriTitrasi Asam Basa di Kelas XI SMA Negeri 6 Lhokseumawe. Jurnal Pendidikan Sains Indonesia, 4(1)220-234.

Berlin,Walanda dan Ratman. 2013. Model Pembelajaran Kooperatif tipe STAD (Student Teams Achievement Division) Dikombinasikan Dengan Media Animasi pada Materi Laju Reaksi Kelas XI SMA Negeri 1 Palu. J.Akademika Kim. 2(3), 134-139.

Roestiya, 1990, Strategi Belajar Mengajar, Rineka Cipta, Jakarta.

Ulihbukit Karo-karo dkk, Ign,1981, Metodologi Pengajaran, CV Saudara, Salatiga.

Zahro, dkk. 2018. Pengaruh Model Pembelajaran Student Team Achievement Devision (STAD) dan Mind Mapping Terhadap Hasil Belajar Siswa Kelas IV SekolahDasar. Jurnal Pendidikan Dasar dan Pembelajaran, 8(2), 196-205.

Zuraidah. 2018. Upaya Meningkatkan Motivasi Belajar Sains dengan Menggunakan Model Pembelajaran Kooperatif Tipe STAD pada Siswa Kelas IV SD Negeri 101768 Tembung. School Education Journal, 8(4), 1720-2355. 